ISSN: 0213-2079 - ISSN electrónico: 2386-3889

DOI: https://doi.org/10.14201/shhmo2020422167193

\title{
EL CONSULADO Y LOS GREMIOS MERCANTILES DE SEVILLA EN LAS FIESTAS POR EL TRIUNFO DE LEPANTO (ENERO-FEBRERO DE 1572) ${ }^{1}$
}

\section{The Consulate of Commerce and the Guilds of Seville on the Occasion of the Celebrations for the Victory of Lepanto (January-February, 1572)}

José Jaime GARCÍA BERNAL

Universidad de Sevilla

jaimebernal@us.es

Fecha de recepción: 11/09/2020

Fecha de aceptación: 20/10/2020

RESUMEN: El presente artículo analiza la participación de los oficios artesanales y del Consulado de mercaderes de Sevilla en las fiestas por la victoria de Lepanto y el nacimiento del príncipe don Fernando de 1572. La primera parte identifica los gremios que sacaron máscaras y carros de invención en estas celebraciones y valora su implicación en función de su riqueza y pujanza en la actividad económica de la ciudad. La segunda parte del trabajo estudia la escenografía y la práctica escénica de algunas de estas representaciones sobre carros. Finalmente se analiza la máscara que sacó la Universidad de cargadores a Indias o Consulado de los mercaderes.

Palabras clave: Consulado de mercaderes; Gremios; Victoria de Lepanto; Fiestas reales; Carros de triunfo; Máscaras; Práctica escénica.

1. Esta investigación se enmarca en el Proyecto de $\mathrm{I}+\mathrm{D}$ «La construcción de un mundo nuevo: circuitos económicos, dinámicas sociales y mediadores culturales en las ciudades atlánticas del sur de España, siglos XVI-XVIII» (HAR2017-85305-P) financiado por el programa estatal de fomento de la investigación científica y técnica de excelencia del Ministerio de Economía, Industria y Competitividad. 
JOSÉ JAIME GARCÍA BERNAL

EL CONSULADO Y LOS GREMIOS MERCANTILES DE SEVILLA EN LAS FIESTAS POR EL TRIUNFO DE LEPANTO (ENERO-FEBRERO DE 1572)

ABSTRACT: This article discusses the participation of the guilds and the Commerce Consulate of Seville on the occasion of celebrations for the victory of Lepanto and the birth of the Prince don Fernando in 1572. The first part identifies the guilds that financed masquerades and carriages values their dedication in relation to their wealth. The second part studies the performing practice in some of these performances above the floats. Finally the text examines the masquerade has been displayed by the Consulate of Commerce.

Keywords: Consulate of Commerce; Guilds; Victory of Lepanto; Royal feasts; Chariots; Masquerades; Performing practice.

Hace ya algún tiempo localizamos uno de los pocos ejemplares existentes de la Relación de las suntuosas y ricas fiestas que compuso, en 1572, el escribano de la ciudad de Sevilla Pedro de Oviedo (Castillejo Benavente: 2019)². El cabildo, por acuerdo de 13 de febrero, encargó a su secretario de cartas un libro que guardase memoria de las celebraciones con que la insigne ciudad honró el fausto suceso de la victoria de Lepanto que, muy pronto, se interpretaría como pronóstico favorable del feliz nacimiento del príncipe don Fernando quien vino al mundo un 4 de diciembre de 1571, transcurridos apenas dos meses de la célebre batalla ${ }^{3}$.

Ambos acontecimientos figuran asociados en el extraordinario lienzo de Tiziano, Felipe II ofreciendo al cielo al infante don Fernando, en cuya composición parece intervino el propio monarca que, despejada ya la amenaza de los partidarios de don Juan en la corte, decidió integrarlo en el imaginario de los fasti imperii de los Austrias (Mínguez, 2011: 277). En las ricas fiestas que relató Pedro de Oviedo el hermanastro del rey, general de la Liga Santa, mantenía sin embargo todavía la aureola de héroe militar que pregonaban los pliegos de cordel. El carro y máscara que costeó el Consulado de mercaderes de Indias lo representó como el nuevo Josué que liberó la cristiandad del yugo opresor del sarraceno (García Bernal, 2008: 221).

Con la invención del Consulado de mercaderes se ponía fin a un ciclo de cinco semanas de espectáculos itinerantes que causaron el asombro de propios y extraños. Danzas, máscaras, carros de triunfo y pequeñas dramatizaciones fueron las albricias con que los gremios y tribunales de la ciudad obsequiaron a sus reyes. En el presente estudio pretendemos subrayar la función que desempeñaron los oficios mercantiles

2. (Oviedo, 1572).

3. Archivo Municipal de Sevilla (AMS), Sec. X. Actas Capitulares, H-1531. Cabildo de sábado, 10 de marzo de 1571 y Sec. XV. Mayordomazgo. Libro de Caja del contador Manuel Diego de Postigo (García Bernal, 2008: 203).

Ediciones Universidad de Salamanca / @®@@ Stud. his., H. ${ }^{a}$ mod., 42, n. 2 (2020), pp. 167-193 
JOSÉ JAIME GARCÍA BERNAL

EL CONSULADO Y LOS GREMIOS MERCANTILES DE SEVILLA EN LAS FIESTAS

POR EL TRIUNFO DE LEPANTO (ENERO-FEBRERO DE 1572)

de la ciudad en la organización de esta fiesta ciudadana de expresión del servicio a la monarquía que tuvo lugar en el ápice del poder económico de la ciudad; no sin menoscabo de señalar, en la segunda parte del trabajo, que los cortejos y representaciones de aquellas jornadas festivas fueron exponente de una etapa de renovación en la práctica escénica de los espectáculos públicos de la España Moderna.

\section{LOS GREMIOS SEVILLANOS Y LAS MASCARADAS DE 1572}

Sederos y lenceros, toneleros y carpinteros, así como los mercaderes de la curtiduría, oficios en expansión en el siglo XVI, sobresalieron por el número de participantes, la riqueza y el aparato escénico de las invenciones que sacaron a las calles para celebrar esta solemnidad. Vinculados a actividades económicas de fuerte impacto en el mercado regional, conectadas, en mayor o menor grado, con las redes transnacionales del comercio atlántico, sus alcaldes, veedores, maestros y oficiales protagonizaron una parte significativa de la producción festiva, disponiendo cuadrillas de figurantes y artificios móviles de gran complejidad. Los oficios relacionados con la confección de artículos de amplia demanda social, particularmente los elaborados del textil (sastres, calceteros y jubeteros; sombrereros o esparteros) pero también los oficios artísticos (los doradores) no le fueron a la zaga en el ingenio y artificio de sus espectáculos. Como tampoco faltaron piezas de entretenimiento, danzas y representaciones a cargo de gremios que, sin la fortaleza de los anteriores, destacaban en su respectivo subsector productivo: los odreros, los tejedores o los roperos.

No era la primera vez que se visibilizaba la lealtad de los gremios a la corona en las fiestas públicas de la etapa filipina. Tan solo once años antes, con motivo del recibimiento que hizo Toledo a Isabel de Valois, los principales oficios de la ciudad imperial se juntaron para salir a recibir a sus reyes formados en compañías de piqueros y arcabuceros que escenificaron una entretenida batalla. En aquella ocasión, sin embargo, no parece que los oficios artesanales interviniesen en la creación de los carros de triunfo que menciona en su Relación Gómez de Castro (Fernández Travieso, 2007: 75-80). Todo lo contrario de lo que sucedió en Sevilla donde, según la información que nos proporciona Pedro de Oviedo, los gremios ejecutaron costosos carros de invención, que escenificaban pequeñas representaciones a partir de guión histórico-legendario aplicado al acontecimiento.

No es casual que el coste de su puesta en escena fuese asumido por los oficios más pujantes y que tributaban mayores cantidades en los repartos de alcabala. Por delante de todos estaba el poderoso gremio de los lenceros que distribuían los lienzos flamencos y bretones que importaban los grandes mercaderes burgaleses (Otte Sander, 2008: 274; Pérez García, 2016: 55-57). En 1576 aportaban más de 23 millones de maravedíes al impuesto sobre las transacciones lo que representaba, según cálculos de Bernal, Collantes y García-Baquero (2008: 234) el 60,3\% de todo

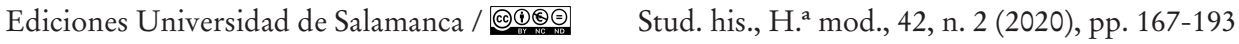


JOSÉ JAIME GARCÍA BERNAL

EL CONSULADO Y LOS GREMIOS MERCANTILES DE SEVILLA EN LAS FIESTAS

POR EL TRIUNFO DE LEPANTO (ENERO-FEBRERO DE 1572)

lo que rindieron los gremios sevillanos en las alcabalas de aquel año. Para costear la invención y máscara de los Trece Reyes del linaje de Nuestra Señora se asociaron a los sederos, los principales proveedores de las prendas que comercializaban y una de las corporaciones de mayor tradición en la ciudad (Collantes de Terán, 1984: 327)4.

Los sastres, calceteros y jubeteros hicieron la representación de la Revelación del nombre del Príncipe en su flamante carro, formado por personajes de bulto que iban vestidos de sedas de diversos colores. Desde las Ordenanças de 1522 (reimpresas por Andrés Grande en 1632) estos tres oficios aparecían agrupados bajo unos mismos estatutos (Bernal, Collantes y García Baquero, 2008: 83) con el fin de vigilar el material, la forma y la calidad de sus labores, mediante el control que hacían sus alcaldes de los talleres y tiendas no solo de sus agremiados sino también de los roperos que cometían competencia desleal al introducir en el mercado jubones hechos a partir de piezas viejas o de tejidos pobres (Ordenanças, 1632: 166). Los roperos también se dotaron de estatutos propios y consiguieron poder fabricar y vender calzas de lienzo basto nuevo, aunque tuvieron que aceptar en 1526, por mediación del cabildo, la visita de los alcaldes de los sastres y jubeteros (Ordenanças, 1632: 169-170). En las fiestas que tratamos representaron una Boda villana de Castilla en la que exhibieron con abundancia el ajuar de la novia 5 .

La contribución del gremio de los roperos a las alcabalas de 1576 es desmesurada respecto al conjunto del subsector textil acumulando el $44 \%$ de lo que se pagó aquel año. Muy superior a la que aportaron calceteros y jubeteros que sumados rozaba el $12 \%$ del total de la confección, una cifra en todo caso nada desdeñable y que refleja el crecimiento de los jubeteros que pasaron de 21 en el padrón de 1533 a 53 en el encabezamiento de 1580 con una tendencia que siguió al alza en la década siguiente (Bernal, Collantes y García Baquero, 2008: 185)6 ${ }^{6}$. El modelo de espectáculo que ofrecieron estos dos gremios competidores en el mercado fue muy distinto. Los roperos contentaron el gusto popular con un cortejo carnavalesco. Los oficios que elaboraban trajes de seda y damasco se esmeraron en poner en escena, sobre un carro de triunfo, una compleja representación alegórica.

Muy relacionados con los anteriores, los tejedores de raso y damasco, y más tarde los toqueros, que empleaban la misma materia prima, alcanzaron amplio desarrollo a lo largo del siglo XVI. La relación de Pedro de Oviedo no los menciona

4. No podemos cuantificar, sin embargo, lo que pudo representar el valor de la producción de telas de seda por estar esta actividad exenta del pago de alcabalas.

5. De amplia tradición en el repertorio festivo, la boda villana o villanesca está documentada en muchas celebraciones españolas del siglo XVI. Gómez de Castro describe una boda burlesca entre las representaciones toledanas por la boda de Felipe II e Isabel de Valois (Fernández Travieso, 2007: 93).

6. No así los calceteros que reducen su representación en el encabezamiento de 1581. En cuanto a los sastres que eran 179 vecinos en el padrón de 1533, carecemos de datos posteriores.

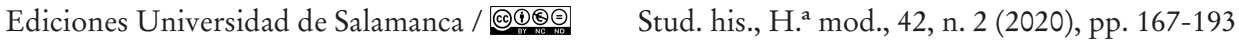


directamente, pero es posible que el carro de invención que desfiló tras el de los sastres, el llamado carro de los Reinos que representaba a la Fe coronando al príncipe, estuviese a cargo de estos oficios si hemos de considerar el esmero que dedicaron en vestir de sedas de colores a los galanes y damas de la máscara que representaban los reinos y ciudades de España.

Siempre dentro del ramo textil, los esparteros, oficio antiguo en la ciudad que contaba con ordenanzas desde 1477 , contribuyó al impuesto de alcabala con un porcentaje semejante al que hemos reseñado para calceteros y jubeteros, que de 1554 a 1588 se situó entre el 10\% y el 13\% del total del sector. En cifras absolutas, en cambio, el crecimiento que se dio en la aportación de los gremios sevillanos al erario público fue mayúsculo entre 1554 y 1576, pasando lo rendido por los esparteros para el impuesto de la alcabala de 58.030 a 636.117 mrs, cantidad esta última solo superada aquel año por los roperos. El motivo elegido para el carro que puso en escena este importante gremio fue el Bautismo del príncipe don Fernando para el que confeccionaron con los materiales propios de su oficio «una cama de campo forrada rica» dentro de la cual se representaba la regia ceremonia.

Emparejado en el tema con este último era el carro triunfal del Nacimiento del príncipe don Fernando que pasearon los sombrereros representando los parabienes y homenajes que recibía el heredero de la monarquía hispana de los reyes y príncipes de todo el mundo. Cabe imaginar que las inclinaciones y gestos de los altos dignatarios irían acompañados de reverencias con gorros, sombreros y bonetes. No debe sorprendernos su participación y protagonismo en estas fiestas (fue el primer carro que desfiló por la plaza de San Francisco el martes 8 de enero de 1572) toda vez que su contribución a las alcabalas es la que más aumentó en números relativos para su subsector entre 1545 y 1576, multiplicándose por 15, y situándose en quinto lugar de lo que aportó a la hacienda real el artesanado textil ${ }^{7}$.

El sector de la piel y cuero que agrupaba el 18\% de los oficios de la ciudad en el padrón de 1533 (Collantes de Terán, 1984: 334) era el que más contribuía, en 1523, a las alcabalas reales, superando incluso al textil ( $24,5 \%$ frente al $23 \%$ ), pero había reducido su peso económico en los años 70 hasta un $12.5 \%$, debido al inusitado auge del comercio, aunque se mantenía como actividad con gran pujanza dentro de las corporaciones artesanales (Bernal, Collantes de Terán y García-Baquero, 2008: 226). Sin embargo, su visibilidad pública en las fiestas que tratamos fue menor. El libreto de Oviedo solo menciona una danza a la villanesca de los odreros, además de la máscara a caballo de los mercaderes de la curtiduría. Espectáculos muy distintos y que se desarrollaron en días diferentes.

7. Su número en cambio tendió a estabilizarse entre 1533 y 1583 (Bernal, Collantes de Terán y García-Baquero, 2008: 185). 
JOSÉ JAIME GARCÍA BERNAL

EL CONSULADO Y LOS GREMIOS MERCANTILES DE SEVILLA EN LAS FIESTAS

POR EL TRIUNFO DE LEPANTO (ENERO-FEBRERO DE 1572)

En la ejecución de la danza participaron también los tejedores que debían ser, en este caso, de paño basto por las prendas que se describen. Los tejedores de lino y lana se encuentran entre los oficios con más antigua presencia documentada en Sevilla y posiblemente tomaron como modelo organizativo el gremio toledano (Collantes de Terán, 1980: 91). Muy precoz fue también la corporación de los odreros que se mencionan en el ordenamiento de pesos y medidas que Alfonso X dio a Sevilla durante su estancia de 1279 (González Arce, 1991: 168). Se han conservado ordenanzas de este oficio desde 1402. Es interesante que ambos gremios, de tan temprana habitación en la ciudad, se agrupasen para este baile villano combinando seguramente los arreos en piel de músicos y danzantes (el tamboril, los borceguíes) con las ropas tejidas en paño.

Muy diferente presentación pública hicieron los mercaderes de la curtiduría quienes monopolizaban el grueso del negocio (30\% de las alcabalas de los años 1576 y 1578 los curtidores de lo mayor) al desfilar en máscara a caballo, acompañados del alguacil mayor, los tenientes y alcaldes de la justicia. Según las ordenanzas de la corporación dictadas por el conde de Cifuentes, uno de los alcaldes mayores de la ciudad debía confirmar anualmente al alcalde y veedor del oficio y tomarle juramento (Ordenanças, 1632: 152) para que ejecutase con probidad una normativa que era muy rigurosa deslindando las distintas fases de la producción del corambre ${ }^{8}$. Sea por este antiguo vínculo o por el estrecho control que siguió manteniendo la ciudad sobre la actividad del matadero y el tráfico de cueros por medio de los fieles ejecutores, los mercaderes al por mayor desfilaron junto a los alcalde y justicias «por las calles y lugares principales de la ciudad, y fue cosa muy de ver» (Oviedo, 1572: 13v).

Conforme avanzó el siglo, el modelo de intervención municipal que asoma en las ordenanzas de los curtidores fue derivando en uno de colaboración entre el gremio y la ciudad, a la hora de elegir los cargos de los oficios. El sistema que parece extenderse en la década de 1560 establecía que los diputados del cabildo de la ciudad designaran a los veedores entre una terna presentada por los maestros del gremio (Bernal, Collantes de Terán y García-Baquero, 2008: 127)9. Una fórmula que, a petición de los jurados, fue sancionada por el Consejo Real en 1572, precisamente el año de nuestras fiestas reales, pero que no evitó la conflictividad que se desprende de la documentación posterior ${ }^{10}$.

8. Para evitar conflictos con los zurradores o tundidores que contaban con sus propias ordenanzas.

9. Así por primera vez en los plateros en 1568, opción elegida posteriormente por los sederos en 1574.

10. No parece que quedara del todo fijado a juzgar de las representaciones que hacen al cabildo los correeros, colcheros y jubeteros (Bernal, Collantes de Terán y García-Baquero, 2008: 128).

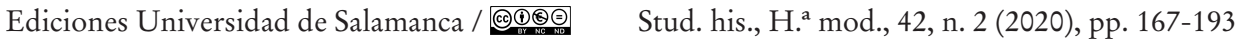


Un sector muy particular en la reglamentación gremial que sacó invención propia en estas fiestas es el que agrupaba a los oficios relacionados con la madera. La intervención de las autoridades municipales se centraba, en este caso, en la compra y almacenaje de la materia prima que trataba de evitar fraudes y reventas (Bernal, Collantes de Terán y García-Baquero, 2008: 110). En la década de 1570 el mercado de la madera está en plena transformación y los proveedores tradicionales, de origen vasco, líderes hasta entonces de la industria naval, compiten con los mercaderes flamencos para introducir naos en la carrera de Indias (Jiménez Montes, 2016: 697). El auge de la demanda vinculada al comercio atlántico se evidencia, una vez más, en el despegue del valor de la alcabala de 1576 que entre los carpinteros multiplica por diez los datos de 1554, y entre los toneleros, gremio que ya era notable a principios de siglo, lo hace por cinco provocando que en 1578 algunos decidan irse de la ciudad (Bernal, Collantes de Terán y García-Baquero, 2008: 187 y 224).

Los toneleros, entre los cuales empiezan a figurar nombres procedentes de los Países Bajos (Abadía Flores, 2010: 176) encabezan el repartimiento dentro del subsector de la madera durante toda la segunda mitad del siglo XVI, superando el medio millón de maravedíes en las fechas que tratamos. También crecen significativamente los carpinteros de lo blanco (340.000 mrs), auge vinculado a la demanda constructiva y en menor medida, los de lo prieto y los carpinteros de ribera (Albardonedo, 2000: 5). En la relación de Oviedo se mencionan, sin embargo, conjuntamente como «oficiales de la madera, toneleros y carpinteros» que se llevaron el premio convocado por el cabildo gracias a la combinación de ingenio y espectacularidad en su cuadrilla y carro de la generación y descendencia del príncipe don Fernando que comentaremos luego.

Para terminar con este repaso por los gremios que participaron en las fiestas reales de 1572 mencionaremos el carro de los doradores, oficio destacado en su sector productivo ${ }^{11}$, que representó la Coronación del príncipe don Fernando condensando en la rica presea real las habilidades de su arte. En sus ordenanzas que se remontan a 1512 se encarece la preparación de sus oficiales en la realización de jaeces y guarniciones de dorado sobre hierro para las armas y arreos (Ordenanças, 1632: 250r). Sin embargo el desarrollo posterior que adquieren los talleres de dorado podría ser relacionado con la demanda de retablos y piezas litúrgicas en claro auge desde mediados de siglo.

Artesanías de gran tradición en la ciudad desde la Edad Media como los olleros que superaron el millón de maravedíes en la contribución de 1576 o los cordoneros cuyo trabajo estuvo muy ligado a la actividad del puerto fluvial y encabezaron la aportación de las alcabalas del sector textil durante la primera mitad del siglo XVI

11. Un oficio en clara expansión en el último tercio del siglo XVI, destacando, por delante de pintores y plateros, en la contribución de las alcabalas de 1576. 
JOSÉ JAIME GARCÍA BERNAL

EL CONSULADO Y LOS GREMIOS MERCANTILES DE SEVILLA EN LAS FIESTAS

POR EL TRIUNFO DE LEPANTO (ENERO-FEBRERO DE 1572)

no tuvieron, sin embargo, una representación festiva propia en las celebraciones reales de 1572. Tampoco menciona el texto de Oviedo a esparteros, sayaleros o manteros, pujantes oficios de la aguja y el telar; ni a zapateros, chapineros, guanteros, guarnicioneros o guadamecileros que sobresalen en el sector de la piel en las décadas centrales de la centuria. Son estas labores, junto con los oficios de la construcción en teja y ladrillo, los grandes ausentes de las representaciones callejeras. En su lugar acudieron al mandamiento del asistente don Pedro López de Mesa con una aportación económica que sirvió para liberar los presos de la cárcel, acto supremo del ejercicio de la justicia por la gracia que, en el contexto festivo de la victoria de Lepanto, simbolizaba la reconciliación de la república cristiana liberada del cautiverio turco (García Bernal, 2008: 205).

\section{LAS FIESTAS REALES DE 1572 EN LA TRADICIÓN DE LOS ESPECTÁCULOS PÚBLICOS SEVILLANOS}

La pericia y el ingenio que hicieron posible este espléndido despliegue de vistosas mascaradas y suntuosos carros no son naturalmente cualidades que se improvisen. Una acendrada cultura corporativa de la puesta en escena y la dramatización para la fiesta subyace a las piezas que se representaron en el invierno de 1572. Desde fines de la Edad Media los juegos de los oficios sevillanos, en ocasiones llamados también entremeses, acompañaban la procesión del Corpus Christi acudiendo a la llamada del cabildo. Con sus pendones, danzas y castillo (pequeño decorado en forma de monte que desfilaba sobre un carro) representaban escenas inspiradas en temas bíblicos, en el oficio litúrgico o en las leyendas de santos. Empleaban para ello la música, la danza y el mimo, componiendo con gestos y movimientos, el sentido de la canción (Granja, 1988: 142). Entre los gremios con mayor tradición de dramatización festiva se encontraban los sastres, calceteros y jubeteros que en 1514 se concertaron para armar un castillo en el que caracterizaron al rey san Fernando y los arzobispos Leandro e Isidoro, a los que acompañaron desfilando un rey de armas, un alférez, dos cantorcicos, diez moros y una mora. Los carpinteros, que representaron, en 1530, el oficio del nacimiento eran asimismo actores y cantores del oficio. Motivo pastoril que repetirían los torcedores de seda y los odreros con la colaboración de Lope de Rueda en autos posteriores (Sentaurens, 1984: I, 51-54).

Odreros, carpinteros, sederos, sastres y calceteros, los mismos oficios que participaron con sus máscaras y carros de representación en las fiestas reales de 1572 . Continuidad pero no sin transformación. En el Corpus de 1554 dejaron de salir los juegos, danzas e invenciones, nos revela un interesante texto recogido por Sentaurens (1984: I, 157), en protesta por la contribución que la ciudad les exigía para la fiesta. El cabildo asumirá, desde entonces, la organización y financiación de la solemne procesión, un relevo en la producción festiva que también se dio en Écija (Rufo 
JOSÉ JAIME GARCÍA BERNAL

EL CONSULADO Y LOS GREMIOS MERCANTILES DE SEVILLA EN LAS FIESTAS

POR EL TRIUNFO DE LEPANTO (ENERO-FEBRERO DE 1572)

Ysern, 1993: 337). Sin embargo los artesanos seguirán acudiendo, a título personal, al concurso que desde entonces convocó la ciudad, compitiendo con las primeras compañías de danzantes y cómicos profesionales (Lleó Cañal, 1975: 17-22). Los premios recompensaban a los carros «de mejor representación e aderezos», a las danzas «de mejores danzantes y vestidos e invenciones» y a las cruces «de mejor invención» (Sentaurens, 1984: I, 172).

Hasta la década de 1580 la aparición de actores profesionales es todavía anecdótica entre los responsables de poner en escena los carros del Corpus aunque ya se mencionan representantes, maestros de hacer comedias o autores de comedias, entre los que se encontraba Zan Ganassa con su compañía actuando en el Corpus de 1575 (Ojeda Calvo, 2007: 65). La mayoría de los que se conciertan con el cabildo en la década de 1570 son artesanos: el dorador Luis Díaz, el escultor Juan Bautista, el carpintero Francisco Bernal, el sastre Diego de Berrío o el tejedor de oro Diego de Pineda. Las listas de autores de comedias y actores amateurs que sacaron carros en el Corpus de Sevilla y dio a conocer Sentaurens (1984: II, apéndice VIII, 12551274) en el trabajo que venimos citando abre la posibilidad de identificar en el futuro algunos de los nombres que la Relación de Oviedo deja en el anonimato, siempre que se localizasen las partidas de gastos que por el momento se resisten ${ }^{12}$.

En todo caso, las invenciones para las fiestas de 1572 se sitúan dentro de la tipología de espectáculos que conocemos para los carros del Corpus de aquellos mismos años y que el mencionado autor condensa en dos modalidades: bien carros con esculturas de bulto o figurantes en posturas estáticas que componían un tema alusivo al acontecimiento (en la tradición de los antiguos castillos y tableaux vivants) introduciendo en ocasiones pequeñas piezas de canto o música; bien pequeñas representaciones dramáticas que utilizaban otros medios de expresión más elaborados como el mimo, el canto o la danza (Sentaurens, 1984: I, 188-189). En las fiestas de Lepanto que nos incumben hallamos espectáculos que se corresponden, en principio, con esta divisoria si bien la práctica escénica resultante de su ejecución (en la medida que puede reconstruirse en la descripción de Oviedo) se abre a dimensiones de fastuosidad, comicidad y lujo que entroncan, a su vez, con la tradición del fasto nobiliario y palaciego que no desconocía la ciudad (Lleó Cañal, 1979: 28-9, 170-185; García Bernal, 2006: 77-120).

Dos años antes, en el recibimiento al rey Felipe II, el cabildo había dispuesto, de acuerdo al guión programático de Juan de Mal Lara (Bernal, 1998: 64), breves representaciones de bienvenida asociadas a las escenas mitológicas o históricas de

12. El Libro de Abecedario de Mayor de Caja de 1571-72 (H-3220) y el Manual de Caja de 1570-1574 (H-3176) solo reflejan los gastos de las alegrías y máscara que hizo la ciudad el día de su fiesta. Las cuentas de Mayordomazgo de 1572 están muy incompletas. Cfr. Inventario Sección XV. Papeles de mayordomazgo. siglo XVI. Volumen V (1559-1591).

Ediciones Universidad de Salamanca / @®@@ Stud. his., H. ${ }^{a}$ mod., 42, n. 2 (2020), pp. 167-193 
JOSÉ JAIME GARCÍA BERNAL

EL CONSULADO Y LOS GREMIOS MERCANTILES DE SEVILLA EN LAS FIESTAS

POR EL TRIUNFO DE LEPANTO (ENERO-FEBRERO DE 1572)

los arcos de triunfo que jalonaban el recorrido. Al traspasar el monarca con sus sobrinos Rodolfo y Ernesto de Austria el arco efímero que coronaba el monte Parnaso, Apolo se alzó esparciendo una nube de flores mientras las nueve musas tañían y cantaban «en acordadas voces» al rey deseado y al valeroso defensor de la fe (Mal Lara, 1998: 68r-69r). No parece probable, en cambio, que las estatuas alegóricas de los siete arcos que se levantaron a lo largo de la calle real para recibir al emperador Carlos V con motivo de sus bodas sevillanas de 1526 escondiesen algún tipo de artificio musical o voz canora que entonase las letras de los romances que explicaban el sentido de las inscripciones latinas, ligadas a las virtudes del monarca (Gómez-Salvago, 1998: 132-148); el único momento de dramatización parece ser aquí el dispositivo o máquina que bajó del arco levantado en la puerta del Perdón del templo hispalense de donde salieron:

ciertos ángeles y con un choro de mozos de choro en figura de las virtudes con suave melodía la recibieron y acompañaron hasta la capilla antigua de Nuestra Señora la Madre de Dios (Gómez Salvago, 1998: 258) ${ }^{13}$.

En todo caso, entre las dos fechas que delimitan las entradas reales del Emperador y su hijo en Sevilla, 1526 y 1570, la práctica escénica de tradición palaciega se fue desarrollando con extraordinaria vitalidad en todas las cortes peninsulares (Ferrer Valls, 1991: 19-83). Basta recordar que con motivo del bautizo de Felipe II en Valladolid la corte imperial había desplegado una espectacular pasarela elevada sobre la plaza de San Pablo, eslabonada por cinco tabernáculos a modo de arcos de triunfo y decorada con pinturas de Valdenesse, por la que transitó el regio cortejo (Pascual Molina, 2013: 153). Entre las alegrías que se celebraron en los días siguientes, de las que fue testigo ocular el embajador polaco Juan Dantisco, merece subrayarse el «gran sarao» de palacio durante el cual tuvo lugar la representación de una fingida embajada morisca que enviaba Zoltana, señora de Arabia y sobrina del Gran Turco, al emperador de los cristianos obsequiándole, por su pericia en el juego de cañas, con una musillera de caballo (Pascual Molina, 2013: 169). Antecedentes de representaciones de embajadas en el fasto nobiliario se hallan en la crónica del condestable don Miguel Lucas de Iranzo, en la embajada del cardenal de Roma representada en Gerona en 1492 y encuentran acomodo en el teatro de Torres Naharro (Ferrer Valls, 1991: 31).

Pero no solo los saraos, también las justas y torneos, los pasos de armas y otros espectáculos de la amplia familia de los juegos ecuestres denotan, a partir de la tercera y cuarta década del siglo XVI, una creciente tendencia a la puesta en escena espectacular, la exageración en el ornato de los caballeros y los suntuosos

13. Transcribe aquí la autora el Ms. 59-1-5 de la Biblioteca Capitular y Colombina: Recibimientos que fueron hechos al invictísimo césar don Carlos V..., f. 22r.

Ediciones Universidad de Salamanca / @®@@ Stud. his., H. ${ }^{a}$ mod., 42, n. 2 (2020), pp. 167-193 
JOSÉ JAIME GARCÍA BERNAL

EL CONSULADO Y LOS GREMIOS MERCANTILES DE SEVILLA EN LAS FIESTAS

POR EL TRIUNFO DE LEPANTO (ENERO-FEBRERO DE 1572)

acompañamientos. Ejemplo de ello lo ofrece el fastuoso torneo que ofreció la corte castellana para recibir, en 1544, a los jóvenes esposos el príncipe Felipe y la princesa portuguesa María Manuela. El torneo, promovido por el almirante don Luis Enríquez que actuó como mantenedor, se celebró el primer domingo de cuaresma en presencia de la princesa y damas de ambas cortes. Un episodio mitológico trazó el guión de un espectáculo multisensorial que encabezó una hidra de siete cabezas. Tras el monstruo iban los carros de triunfo de cada cuadrilla amenizados por copias de ministriles. Las invenciones rivalizaban en creatividad, riqueza, ornato $y$, por encima de todo, en espectacularidad. Animales fingidos (cisnes, dragones, elefantes) o al vivo (caballos, cabras de las Indias o hasta un dromedario) tiraban de las carrozas que representaban pequeñas escenas con personajes alegóricos (el Tiempo, la Ocasión, la Fortuna), una fórmula que veremos repetida en las cabalgatas de Sevilla. Lo mismo puede decirse de los acompañamientos fabulosos y el atrezzo abundante en elementos que simbolizaban lujo y distinción (Pascual Molina, 2013: 229-242).

El tema caballeresco se entreveró, en esta función, con la fábula del mito clásico (Ferrer Valls, 1991: 23) y ambos argumentos quedaron, a su vez, apagados por el brillo de las libreas, celadas y escudos de los aventureros; empequeñecidos por la espectacularidad de los carros que iban tirados por enormes animales contrahechos (Borrego Gutiérrez, 2014: 189-190). Y sobre todo, vaciados de su genuino sabor cortesano que parece diluirse dentro de un espectáculo total para un público masivo y variopinto. La aparición de personajes bufonescos y escenas paródicas forma parte de este mismo proceso de transformación de la tradición nobiliaria y de la ética caballeresca, con su imaginario de castillos y doncellas, en cortejos festivos de gran espectacularidad y artificio que buscan epatar y sorprender, entretener y hacer reír (Cátedra, 2000: 112). De este modo, en el torneo que se hizo en Salamanca, en 1543, con ocasión de las mencionadas bodas regias, la princesa que asistía a la función puso los ojos en el escuadrón de don Diego de Acevedo que sacó una sierpe donde se escondían doce caballeros armados, dispuestos a asaltar un castillo. El entremés (así calificado por el cronista) dio «mucha gracia a este torneo» (Borrego Gutiérrez, 2014: 190).

La asociación del argumento caballeresco a invenciones de aparato no deja de recordarnos, desde luego, a las muy estudiadas fiestas de Binche, en un ambiente de refinada cortesanía (Heartz, 1975: 311-328). A las milanesas que ofreció Hernando de Gonzaga y describió Calvete de Estrella (2001: 68-70). Pero puede rastrearse igualmente en los fastos castellanos que patrocinó el conde de Benavente en su villa zamorana para agasajar al príncipe don Felipe donde se exhibieron elefantes, castillos y galeras (Ferrer, 1993: 180; Borrego Gutiérrez, 2014: 194).

No faltará el elemento espectacular, como tampoco el acento de comicidad, en algunas máscaras sevillanas de las que hizo mérito Pedro de Oviedo. Era tiempo

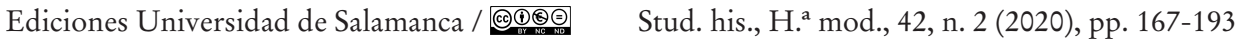


JOSÉ JAIME GARCÍA BERNAL

EL CONSULADO Y LOS GREMIOS MERCANTILES DE SEVILLA EN LAS FIESTAS

POR EL TRIUNFO DE LEPANTO (ENERO-FEBRERO DE 1572)

de carnestolendas y el regocijo de la buena nueva derivó en un ambiente de risa abierta y derrota de la gravedad que se aprecia singularmente en la invención del Padre de las mujeres y en la máscara de los estudiantes, aunque no faltara en los carros de invención más solemnes. Las escenas de estos últimos expresan la magnificencia y compostura de matriz cortesana, vestida de un lenguaje alegórico en el que se cuelan, en contrapunto, personajes del registro rústico, la tradición pastoril, o sencillamente de la actualidad histórica, que reclaman la atención del espectador y despiertan su hilaridad.

\section{LAS REPRESENTACIONES DE LOS GREMIOS: LOS CARROS DE INVENCIÓN}

Del rico repertorio de espectáculos que se escenificaron en las fiestas reales sevillanas del invierno de 1572 pueden distinguirse varias escalas de actuación, marcadas por significativas llamadas del escribano Oviedo que advierte «formaban el carro personajes de bulto», o por el contrario, «todas estas figuras yuan al vivo», e incluso: «yuan al vivo representando». Con las danzas y máscaras sucede lo mismo. Al genérico «salió la máscara» o «iban en máscara» suele precisarse «de a caballo» cuando prima la modalidad ecuestre de la cabalgada nocturna asociada a la nobleza, y en una ocasión (la que sacaron los mercaderes de la curtiduría), se refiere a ella como «danza y caballería» para subrayar la faceta coreográfica de la misma. Cuando el cortejo es tematizado y puede derivar en una breve representación el autor une «invención» a «máscara» para significar que es una pieza única, ligada por el mismo guión (por ejemplo, la máscara e invención de los sederos y lenceros, o de los colegiales de Maese Rodrigo).

Las representaciones sobre carros, en las que nos centraremos prioritariamente, dominan el discurso del escribano del cabildo. Fueron las más vistosas, con mayor aparato escenográfico y ornamental; asimismo, las que demostraron mayor elaboración en su práctica escénica aunando lenguajes y tradiciones diversas. La mayoría de ellas hacían alusión al natalicio del príncipe don Fernando evocando escenas propias del ritual cortesano (el bautizo) o del imaginario áulico (la coronación alegórica, su generación y descendencia, la inspiración divina de su nombre). La invención que el viernes 11 de enero sacaron los sastres, calceteros y jubeteros ofreció uno de los resultados más fecundos desde el punto de vista del entrecruzado posible de los recorridos que había ensayado la escena tardomedieval y renacentista ${ }^{14}$. El teatro del carro representaba el decreto providencial del Nombre del heredero a los reinos e iba precedido de una máscara «de quarenta de a cauallo» encabezada

14. El impresor Hernando Díaz lo destaca en la tipografía (14r).

Ediciones Universidad de Salamanca / @®@@ Stud. his., H. ${ }^{a}$ mod., 42, n. 2 (2020), pp. 167-193 
por cuatro clarines y un heraldo armado que portaba el pendón de la ciudad ${ }^{15}$. Sobre la plataforma móvil reclamaba los ojos del público el Silencio y la Atención, dos figuras de bulto, que se identificaban por sus gestos. En seguida venían otros dos personajes, estos al vivo, que en ropa de pastores representaban el Placer y el Regocijo. Asumiendo la función prologal propia de la loa en el primitivo teatro castellano (Hermenegildo, 2009: 173), los rústicos:

conferían entre ambos un verso castellano de la victoria del señor don Iuan de Austria y de la buena venida de la Reyna nuestra señora en España y de su preñez, y cómo della se esperaua felice sucesso y buena fortuna en estos Reynos, y varón para vniuersal bien dellos y del mundo (Oviedo, 1572: 14v-15r).

Apenas había concluido el introito cuando entró un quinto personaje, el Contento, que daba la nueva del nacimiento del heredero. Comenzó propiamente aquí la breve representación. Los dos pastores y el mensajero acudieron al príncipe a reconocerle por señor. El niño estaba en brazos de su ama con la mantilla de la ceremonia. Y sus padres, los reyes, ataviados a lo honesto, se inclinaron para pedir en oración a Dios les revelase el nombre de su hijo. Acompañaban la escena cortesana las tres virtudes teologales, representadas por actores como los anteriores, suponemos que oficiales de la corporación textil. Fe, Esperanza y Caridad, juntamente con el Contento, Placer y Regocijo, cantaron entonces el salmo Laudate dominum omnes gentes momento en el que un dispositivo abrió una nube artificial que campeaba en medio del carro. Salió de ella un ángel que declaró el nombre del príncipe: «Del alto cielo viene decretado / Que el príncipe, Fernando sea llamado». Por último, los seis personajes alzaron al príncipe mientras cantaban el Te Deum y tocaban los ministriles (Oviedo, 1572: 14v).

Canciones litúrgicas o villancicos ponían broche final a las églogas políticas del siglo XVI. Así también los pastores que acuden a hacer pleitesía al rey pueden encontrarse en el teatro de Encinas y Madrid, a veces, cumpliendo la función del portador de la noticia que llama a la implicación del público (Bustos Táuler, 2016: $6,11,22)$. Todos estos tópicos estuvieron presentes en la concepción de la escena del carro de los sastres junto a un elemento que procede del teatro litúrgico aunque pronto pasó también al fasto cortesano (Ferrer Valls, 1987: 21) y a la fiesta cívica: el rompimiento del cielo del que desciende el ángel comunicador del designio divino (Quirante Santacruz, 1995: 11-23).

Había ya un camino avanzado en la práctica escénica de las cortes señoriales para que este tipo de propuestas cristalizase en los carros de invención de 1572. En el comedio del siglo las églogas pastoriles dan un giro hacia temas profanos, ligados a circunstancias de fasto, mientras que los dramas políticos se impregnan, a su vez,

15. Acerca de la función heráldica de los músicos vid. Bejarano Pellicer (2010: 319-334).

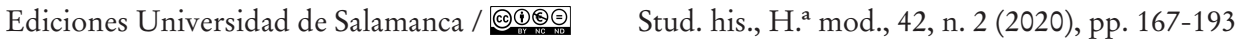


de elementos bucólicos y pastoriles (Reyes, 2018: 15). Paralelamente se extiende el recurso, tanto en la escena religiosa como en la corte, a figuras morales (la Ceguedad, la Fe, la Fortuna) o alegorías políticas (España, sus reinos) que concentran el clímax dramático, ligado a gestos rituales (inclinación, oración) y en torno a objetos (la mesa del banquete, el trono, la corona) que funcionan como auténticos iconos escénicos, detectables, asimismo, en las didascalias de algunos autos de tema bíblico del códice de autos viejos (Hermenegildo, 2009: 179).

En el marco de nuestras fiestas reales hallamos evidencia de esta práctica escénica en el carro triunfal de la entrega del príncipe don Fernando a la Fe que había sido ideado por tres instituciones vinculadas con la carrera de Indias: la Casa de la Contratación, la Aduana y la Casa de la Moneda que cabalgaban por delante, personificadas en figura de tres damas con tocado romano. La escenografía del carro representaba la torre de la iglesia coronada por la Fe, según el flamante remate del campanario de la Catedra ${ }^{16}$ y las dos columnas de Hércules sobre las cuales se asentaban el Mundo y la Fama ${ }^{17}$. Los tres hitos se enfrentaban al trono de la reina Ana de Austria, quedando en medio un espacio ocupado por los otros tres personajes o alegorías políticas: España, Sevilla y el río Betis, igualmente encarnadas por actores. La representación consistió en un diálogo entre la reina y los tres personajes morales que reclamaban al niño. Preguntada la Fe para qué le quería, dijo «que para echalle su bendición y para que la ensanchasse por el mundo y la defendiesse de luteranos e infieles». A la misma pregunta, el Mundo respondió «que para seruille y obedecelle y reconocelle por señor». Interpelada en tercer lugar la Fama, argumentó que «para diuulgalle por el mundo y dar la nueua de cómo auía nacido vn gran príncipe». En este punto, llegaban España, Sevilla y Betis, personajes con una función mecánica que precipitan el desenlace. Acudían a la corte a darle el parabién a su majestad quien se lo agradecía entregando el príncipe a España que, a su vez, lo ofrecía a la Fe. La breve pieza concluía «cantando canciones en loor del príncipe» (Oviedo, 1572: 9r).

A diferencia de los parlamentos de los personajes alegóricos de la entrada de Ana de Austria en Burgos, en 1570, que pedían licencia al pasar con sus carros delante del rey Felipe II (Varela Ledo, 2016: 157-158) en la representación sevillana, y en ausencia del monarca, la escena ritual de las norabuenas se desarrolla en el seno de una representación alegórica con sentido pedagógico y fin de adoctrinamiento moral: es la Fe, por encima de otros valores, la que recibe por encomienda de España la ofrenda de su real servidor. Las figuras alegóricas, visibles en la altura de la torre y las columnas, dialogan con su majestad en el trono, hito visual del otro extremo del

16. Acabado apenas tres años antes de la celebración de estas fiestas.

17. Que el asistente conde de Barajas mandó trasladar a la Alameda en 1574 (Albardonedo Freire, 2015: 427). 
JOSÉ JAIME GARCÍA BERNAL

EL CONSULADO Y LOS GREMIOS MERCANTILES DE SEVILLA EN LAS FIESTAS

POR EL TRIUNFO DE LEPANTO (ENERO-FEBRERO DE 1572)

carro, mientras los personajes históricos se desplazan por el llano haciendo posible la entrega del príncipe.

La representación del carro de los doradores repite parte de estos elementos dramáticos (los personajes morales, el protagonismo de la Fe que es punto de fuga de la acción dramática) al tiempo que potencia otros (la corona, objeto-icono ritual) e introduce de nuevo el artificio escénico en forma de un globo que se abrió para dar lugar a la aparición del niño heredero. El motivo de la invención fue, como se habrá ya deducido, «la coronación del príncipe nuestro señor» (Oviedo, 1572, 11r). Las virtudes clásicas iban en las cuatro esquinas del carro y podían identificarse por sus insignias: la espada, la columna, el vaso y el espejo. Representadas al vivo y aderezadas al estilo romano, centraban su atención en un pedestal de altura de tres varas sobre el que se pintaron «muchas batallas y la victoria que el señor don Iuan ouo contra el armada turquesca» (Oviedo, 1572, 11v). El icono militar remataba en un mundo sobre el cual se había colocado la figura de la Fe en una silla ricamente tallada.

La entrada de un emisario, vestido a la villanesca, dio principio a la representación. Era el Deseo que pedía albricias a la ciudad del feliz nacimiento del príncipe. Seguidamente se dirigió a las virtudes y «diuulgáuales esta dichosa nueua» (Oviedo, 1572, 12r). No dice más el cronista Oviedo pero lo suficiente para que podamos identificar al Deseo con otros personajes que desempeñan una función introductoria en el fasto público, por medio de la narración, apoyada en el gesto, apelando a la ciudad (en este caso) y relatando a las Virtudes la noticia. Ya lo advertimos en el personaje del Contento del anterior carro y puede registrarse también en la figura del truhán que en el torneo de Burgos de 1570 declara en romance el propósito de la representación (Borrego Gutiérrez, 2014: 197).

Sabedoras de la feliz noticia, Templanza, Fortaleza y Prudencia acudían, con gran regocijo, a dar el parabién del nacimiento a la reina; instante en el que se abría el mundo por la parte de Europa y salía un hermoso infante con la letra de oro que decía: Ferdinandus. VI. Defensor Fidei. Representaba al heredero un niño de dos años vestido de raso carmesí que avanzó poco a poco hacia el trono de la Fe. Cuando estuvo cerca el actor que representaba la figura alegórica le levantó y abrazándolo lo sentó en sus rodillas. Cuida particularmente Oviedo estos detalles afectivos para subrayar el íntimo trato de una decisión providencial. La puesta en escena debía crear la atención necesaria en el público para que no pasara desapercibido el momento en que la $\mathrm{Fe}$ «se quitaua la corona y la ponía al príncipe» expresando en un verso -que el relacionero transcribe para eternizar el efímero- la real presea que recibía de la Christianísima España convirtiéndolo en defensor de la fe por la doble herencia de los Austrias ${ }^{18}$.

18. «Pues que tu real persona/ al mundo no será extraña/ esta suprema corona/ te la presentan y endona/ la Christianíssima España» (Oviedo, 1572: 12v).

Ediciones Universidad de Salamanca / @®@@ Stud. his., H. ${ }^{a}$ mod., 42, n. 2 (2020), pp. 167-193 
JOSÉ JAIME GARCÍA BERNAL

Hemos de imaginar que los ministriles y vihuelas de arco que acompañaban este carro tañeron al final de la representación, o en otros momentos del recorrido, mientras la Fe, en su trono, esparcía letras que decían: «Philipe y Fernando son / los de mi escudo y blasón» (Oviedo, 1572: 12v). El complemento musical (primero el clarín, luego los instrumentos de cuerda) crearon la atmósfera imprescindible para realzar una acción dramática articulada en torno a la corona de oro y algunos otros objetos auríferos (los vasos de la Templanza, la letra de oro que lucía en el pecho el principito) que subrayaban la honra del gremio de los doradores, artífice de esta invención ${ }^{19}$.

De mayor espectacularidad aún fue la invención y máscara de los toneleros y carpinteros, oficios, como antes se dijo, de gran pujanza en una ciudad portuaria como Sevilla y que habían tenido un papel muy activo en sus fiestas civiles. Para esta ocasión presentaron el carro de la generación y descendencia del príncipe don Fernando que fue precedido por un fabuloso cortejo que formaban los nueve barones o caballeros de la Fama, y algunas piezas cómicas que en seguida comentaremos ${ }^{20}$. Gustó mucho y recibió el premio del cabildo.

Lo describiremos brevemente para fijarnos, a continuación, en las novedades que presentó desde el punto de vista de la puesta en escena. Iban por delante los clarines proclamando la fama de los personajes de la máscara. Esta, con sus atributos de ojos y lenguas, lucía sobre un dromedario vivo, revestido de larga ropa ajironada en tafetán blanco, colorado y azul (García Bernal, 2018: 536). Le seguían los tres gentiles en camellos vivos, ensillados sobre ricas alfombras. Los héroes cristianos iban armados a caballo cada uno con su estandarte. Los ministriles desfilaban a continuación amenizando un pequeño carro en el que iba el moro Jarife con un león también al vivo. Finalmente, el carro de la generación, presidido por Febo, iba tirado por un elefante artificial que echaba fuego por la trompa.

Dos elementos llamaban la atención del cronista en esta portentosa cabalgata. Los grandes animales vivos que ya se habían visto en la corte de Valladolid, pero menos en Sevilla ${ }^{21}$. Y su uso para amenizar una escena paródica. En efecto, el león «muy hermoso» llevaba una corona de oro y el Jarife quedaba ridiculizado como

19. Los esparteros participaron asimismo en estas fiestas con un carro posiblemente de figuras de bulto que «hazían una corona de oro y la presentauan al príncipe» (Oviedo, 1572: 11r). Acerca de la función de la música en las máscaras y carros de la Sevilla barroca consúltese Clara Bejarano Pellicer (2015: 154-179).

20. Tema medieval de gran éxito en los fastos del Renacimiento que parece tener origen en la obra de Jacques de Longuyon, Voeux du paon, de principios del siglo XIV (Vallejo Naranjo, 2008: 142-144).

21. El mismo príncipe don Felipe, acompañado del duque de Alba, había participado en el mencionado torneo de Valladolid de 1544 con un camello vivo que coronaba un castillo donde asomaba el bufón Perido de Santervás (Pascual Molina, 2016: 130). Por su parte, don Luis

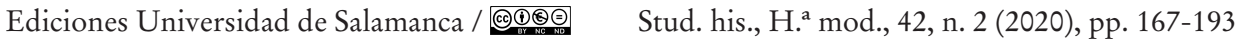


JOSÉ JAIME GARCÍA BERNAL

idólatra «que le yua halagando a vezes y otras haziéndole dar bramidos» (Oviedo, 1572: 19r). Sin duda haría las delicias del vulgo, a modo de entremés cómico, entre el cortejo de los nueve caballeros y el trono de Febo. Este último, como se ha dicho, iba en un carro tirado por un elefante contrahecho que nos recuerda a los animales artificiosos que jalonaron los recibimientos del Emperador en Italia, después de la campaña de Túnez (García Bernal, 2018: 524).

La diosa Venus ensillaba al gran paquidermo, portando sus insignias (el lucero y la manzana) que anunciaban el pronóstico (en un rótulo con su letra) de la fama venidera del príncipe. Febo, padre universal de toda generación, campeaba en su trono sobre cuatro gradas que simbolizaban por sus colores los cuatro elementos e iba tocado por doce rayos significando los del zodiaco. Al pie del graderío estaban las tres parcas de la mitología clásica que proclamaban los siglos de consuelo que correrían para las nuevas generaciones gracias al nacimiento de este heredero sin que Atropos (con las tijeras caídas) pudiera poner fin «a su imperio ni a sus días». Parece que las tres moiras fueron interpretadas por actores o actrices que «dezía(n) con un verso» una parte del mensaje que aquí hemos abreviado (Oviedo, 1572: 20r).

A los lados de Febo le asistían Iris y Lucina, diosa de los partos, que sostenían el arco del cielo sobre el cual crecía un árbol de cuyas ramas pendían, como frutos, los reyes, padres y abuelos del príncipe. Precisa Pedro de Oviedo que todos estos personajes «yuan al viuo» por lo que hemos de suponer que algún tipo de estructura escalonada los sostenía. Completaban la escena las cuatro torres de las esquinas sobre las que iban la Fe, Astrea (símbolo de la Justicia), Marte (la fortaleza) y Palas (la prudencia). Finalmente, en la delantera del carro, un personaje que representaba la ciudad de Sevilla portaba un corazón abierto en la mano en el que iba cifrado el nombre del príncipe.

Sobre esta elaborada escenografía, que asociaba la mitología clásica a la genealogía de la casa de Austria, se hizo una representación que fue concebida como declaración o explicación de su significado. Una danza de tres gracias y tres zagales, que irrumpieron en escena, dio el tono de alegría a la pieza, pues Gozo, Placer y Deseo, aderezados a lo pastoril, bailaron con Aglaya (la belleza), Euphrósine (el Júbilo) y Pasítea (el descanso) en lugar de la más habitual Talía. Mercurio interrumpió la danza para declarar, en un largo parlamento, «toda esta invención del carro». El discurso que recitó el mensajero de los dioses queda recogido en tres hojas del impreso de Díaz, pero no es nuestra intención agotarlo aquí. Baste con subrayar la función conativa que desempeña en la dramatización de la pieza al reclamar la atención de un público selecto ante el que se ejecutaría la representación en la plaza de San Francisco: «Illustrísimo Senado/ yo soy Mercurio diuino/ del alto cielo embiado/

Cortés, marqués del Valle, sacó un pequeño carro tirado por «dos cabras de Indias» (Pascual Molina, 2013: 237-238). 
con mensaje desseado/ deste bien que al mundo vino». Tratando de conectar la escena con los espectadores, acude a recursos propios de la loa como el elogio de los asistentes: «En esta venida mía/ a solo manifestar/ La singular alegría/ de esta ciudad singular/ en este dichoso día» (Oviedo, 1572: 22r). Sin olvidar la vocación ecfrástica del género relacionero, convirtiendo las figuras en personajes de un romance versificado.

De este modo el recitativo de Mercurio da vida al cuadro para que sin ocurrir en la escena se invoque en la memoria y se dibuje con la imaginación la actualización del mito, produciéndose el efecto de abismación metafórica que Alfredo Hermenegildo reconoce en los romances y villancicos de los autos del primer teatro castellano (Hermenegildo, 2009: 178). Tras el largo parlamento, vino la sentencia dicha por la boca de Febo que cerraba el sentido de la invención y máscara:

Que aquellas fieras y moro Xarife que las domesticaua se venían a rendir en nombre de todos los reyes del África, y del Xarife, a la grandeza del príncipe nascido, y ofreciendo sus fuerças contra el común enemigo dellos y de todos, que es el turco ya vencido y lançado de la mar, por el señor don Iuan de Austria.

\section{EL CONSULADO DE MERCADERES DE SEVILLA Y LA REPRESENTACIÓN DE LA VICTORIA DE LEPANTO}

En la invención de los oficios de la madera el argumento de la batalla de Lepanto queda ya planteado como la gran victoria que abría un tiempo nuevo: un mediterráneo bajo hegemonía de un príncipe cristiano al que rendirán homenaje todos los sátrapas y pachás del Oriente. La máscara de la Universidad de cargadores a Indias, que vamos a examinar a continuación, regresó al motivo de Lepanto, pero desarrollando con más detalle las circunstancias y personajes de la impar batalla y abundando en el significado providencial del acontecimiento que encuentra analogía en el pasaje veterotestamentario de la batalla de Josué contra los amalequitas (García Bernal, 2008: 221).

Hemos de considerar, por otra parte, que el del Consulado fue el último espectáculo del gran ciclo festivo que había comenzado la víspera del día de Reyes y que se celebró un 17 de febrero, en pleno carnaval. La presencia de notas burlescas asociadas al cortejo de los turcos contrasta con la solemnidad y prestancia de la cuadrilla cristiana. Pero el rasgo que destaca Oviedo, para distinguirla de otras representaciones de aire más popular que no hemos podido tratar esta vez, fue su "gala y riqueza», repartida por igual entre los protagonistas de ambas armadas, así como el ingenio

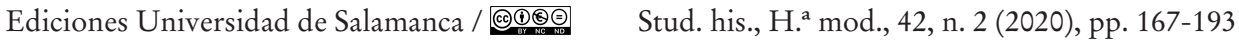


JOSÉ JAIME GARCÍA BERNAL

EL CONSULADO Y LOS GREMIOS MERCANTILES DE SEVILLA EN LAS FIESTAS

POR EL TRIUNFO DE LEPANTO (ENERO-FEBRERO DE 1572)

(«la curiosa invención») que ponía en escena por las calles de Sevilla la batalla que corría en boca de todos y se romanceaba en las relaciones de sucesos ${ }^{22}$.

De las palabras del cronista se deduce que la persona clave en la organización y financiación del espectáculo fue don Juan Gutiérrez Tello, alférez mayor de Sevilla y juez tesorero de su majestad. Con amplia experiencia como funcionario de la Casa de la Contratación desde principios de la década de $1560^{23}$, Gutiérrez Tello asumió, en 1575, por encargo de la Corona, la cobranza de las grandes rentas y consignaciones de Sevilla, Córdoba, Écija, Jerez y Carmona ${ }^{24}$. La máscara de los mercaderes salió de su casa, formando la última cuadrilla el prior y cónsules de la universidad. Pedro de Oviedo identifica cuatro nombres del ilustre senado mercantil. El mencionado Tello que desfilaba como juez de apelación del Consulado. El prior, Diego Díaz Becerril, y los dos cónsules, Alonso de Cazalla de León y Francisco Martínez Baeza (Oviedo, 1572, 46v). En los listados que publicó Antonia Heredia (1983: 497-498) el mercader Diego Díaz Becerril figura, desde 1562, desempeñando los cargos de cónsul o prior en distintos triunviratos hasta 1578 en que ejerce por última vez el priorato. También se repite el nombre de Alonso de Cazalla en varias ocasiones hasta alcanzar en 1584 el honor de ser prior de la universidad, algo que no ocurre con Francisco Martínez cuya participación en el núcleo directivo que controlaba el tribunal fue más episódica (Heredia Herrera, 1983: 496). El mercader Diego Díaz Becerril es figura representativa de una generación de comerciantes que había amasado su fortuna en el comercio con Tierra Firme y Perú, diversificando su inversión a su regreso a la península y alcanzando notoriedad y prestigio en el exclusivo círculo de los mercaderes del Consulado (Sardone, 2016: 3264).

No hay que olvidar que la institución mercantil sevillana, después de varias tentativas infructuosas, había sido creada en 1543 como tribunal con jurisdicción privativa desgajada de las competencias de la Casa de la Contratación (Bernal, 2012: 11,14-15) pero pronto fue asumiendo otras competencias judiciales y gremiales, y lo que es más importante, ampliando las mercantiles, convirtiéndose, ya en siglo XVII, en uno de los principales prestamistas de la corona (Vila Vilar, 2016: 73-75, 95). En

22. Numerosas y en distintas lenguas las que se difundieron sobre el singular acontecimiento (García Bernal, 2009: 7)

23. AGI. Contratación, 4680: 1562. Cargo de Juan Gutiérrez Tello, tesorero de esta Casa, de lo procedido de las minas. Data que se libran a Juan Gutiérrez Tello en los de su cargo procedidos de la plata que se trae de las minas de Guadalcanal, Aracena y otras partes.

24. Encargo que desempeñó desde septiembre de 1575 hasta 1580 , que fue suspendido, regresando a esta función en 1582. AGI. Contratación, 4682B. Capítulo de carta de su majestad dirigida al conde de Barajas (10 de septiembre de 1575): «que se cobre, recoja y entregue en la dicha casa todo el dinero de las dichas consignaciones». Otra cédula en el mismo sentido dirigida a las ciudades de Córdoba, Écija, Jerez y Carmona: «ser recojan y junten en esta dicha ciudad de Sevilla y en la nuestra Casa de la Contratación para que de allí se lleven a las partes y lugares que mandaremos para los gastos de las armadas y fronteras y galeras (...)».

Ediciones Universidad de Salamanca / @@@ Stud. his., H. ${ }^{a}$ mod., 42, n. 2 (2020), pp. 167-193 
JOSÉ JAIME GARCÍA BERNAL

EL CONSULADO Y LOS GREMIOS MERCANTILES DE SEVILLA EN LAS FIESTAS

POR EL TRIUNFO DE LEPANTO (ENERO-FEBRERO DE 1572)

1572, data de nuestras fiestas, ya tenía la facultad de inspeccionar los navíos y nombrar escribanos de flotas pero aún no había sido autorizada para designar a los maestres de plata ni controlaba los sustanciosos beneficios que, pese al riesgo inherente a la operación, iba a proporcionar la administración de la avería (Álvarez Nogal, 1998: 1368). Sin embargo, desde 1555, parece haber servido a las urgencias de la Corona (Rodríguez Vicente, 1977: 216) y su prestigio crecía, sumando honores en clara rivalidad con la propia Casa ${ }^{25}$, hasta obtener la igualdad de asientos en las concurrencias con el tribunal de la Contratación ${ }^{26}$.

La ausencia del libro de elecciones y de los libros de cuentas para el año 1572 en el archivo del consulado nos priva de poder reconstruir los gastos de la lujosa mascarada que nos ocupa (Heredia Herrera, 1983: 489) pero debieron hacer honor al concepto de sumptvosas y ricas que proclama la portada del impreso. Desde el punto de vista del dispositivo escénico el cortejo se incardina en una tradición de fastos por triunfos militares que nos remite, incuestionablemente, a los del Emperador a su regreso de las campañas africanas, pero al mismo tiempo contiene rasgos propios de los fastos filipinos con el trasfondo, no lo olvidemos, de la guerra de Granada que dejó honda huella en la ciudad. El citado Gutiérrez Tello protagonizó un sonado conflicto de preeminencias en ocasión del envío de tropas al socorro de Granada. Y esto es solo un botón de muestra de la estrecha relación que tuvo la oligarquía sevillana con el proceso de conquista, deportación y asentamiento de los moriscos granadinos en la baja Andalucía (Fernández Chaves y Pérez García, 2009: 61-63).

La fiesta comenzó irrumpiendo una sierpe en la plaza de san Francisco, centro de la vida cívica de la ciudad. El artificio mecánico, habitual del corpus sevillano (Lleó Cañal, 1980: 39) iba, esta vez, coronado por Alí Bajá, el comandante de la flota otomana. Una gran letra lo identificaba junto con medallones donde estaban esculpidos los antecesores del gran turco. Ademanes y atributos representaban «no solamente grandeza y ferocidad, más confianza de la victoria». La marlota de seda, la cimitarra y la media luna completaban su atrezzo. El grosero figurón iba preñado de cohetes y «en la boca un gran cañón a manera de lengua lleno de póluora» (Oviedo, 1572, 36r). Por delante, sentado en la misma sierpe, iba el truhán Cazoleta, con un gran mostacho, la aljaba y las flechas, al modo turquesco. El enorme monstruo, imagen misma de la desmesura asiática, dio una vuelta en la plaza con gran cantidad de turcos, vestidos de sedas, con medias lanzas y arcos, quedando en medio del coso. A renglón seguido apareció la cuadrilla cristiana: un buen número de arcabuceros en traje de gala antecediendo a don Juan de Austria que iba a caballo e identificado con un estandarte en el que se pintó la hidra que decapitó con su hazaña. También

25. Como se desprende del historial de sus méritos y servicios a la Corona: AGI. Consulados, 101.

26. AGI. Consulados, L 44. Abecedario de Menacho Soto.

Ediciones Universidad de Salamanca / @®@@ Stud. his., H. ${ }^{a}$ mod., 42, n. 2 (2020), pp. 167-193 
JOSÉ JAIME GARCÍA BERNAL

EL CONSULADO Y LOS GREMIOS MERCANTILES DE SEVILLA EN LAS FIESTAS

POR EL TRIUNFO DE LEPANTO (ENERO-FEBRERO DE 1572)

dieron una vuelta antes de iniciar la escaramuza. Cristianos y turcos intercambiaron flechas y arcabuzazos. Los unos gritando Santiago y España, los infieles «dando alaridos y haciendo algazaras» (Oviedo, 1572: 37r). Luego sacaron espadas y alfanjes hasta que los sarracenos fueron hechos prisioneros. A continuación, el caballero don Juan lanceó la Sierpe que vomitó en fuego toda la hinchazón de su deformidad. Y así concluyó la primera parte del espectáculo.

Después salió la máscara que representaba la batalla de Lepanto, encabezada por trompetas italianas que acompañan a un hombre de armas con el estandarte de Sevilla. Volvía a desfilar el personaje de don Juan acompañado de la cuadrilla de los diez generales que estuvieron en la batalla. Pedro de Oviedo señala que llevaban máscaras diferenciadas que darían autenticidad a la representación. Le seguía la cuadrilla de los diez turcos prisioneros, también con máscaras «con tanto artificio hechas que representauan tristeza». A los cuellos llevaban argollas, signo de su cautiverio. Montaban a la gineta con zaragüelles y borceguíes marroquíes. Uno de los turcos principales sacó una letra que declaraba, como en la popular novela del Abencerraje, la pesadumbre que le embargaba de sentirse prisionero y esclavo de amor $^{27}$.

Una vez pasada la cuadrilla turca, desfiló la de los diez reyes que representaban otros tantos reinos de la monarquía española. Armas, cetros y coronas los hacían reconocibles. Finalmente, los tres personajes de la Liga Santa en figura y hábito de damas: Roma, España y Venecia. Su descripción es tan prolija que podría escribirse un tratado de tejidos y piedras preciosas solo a partir de las sayas y tocados. Roma iba en medio con un estandarte en el que estaba pintado el papa Pío V, asistido por Felipe II y el Dogo veneciano «imitando a lo que Hur y Aarón hazían con Moysén quando oraua en la batalla contra los Amalequitas» (Oviedo 1572, 44v). La dama que representaba España llevaba un estandarte con la letra latina del defensor de la fe, que hemos visto ya varias veces en estas fiestas, ajustada aquí a la historia de Josué cuando venció al ejército de los amalequitas, mostrando en la otra parte del pendón el diorama icónico de la batalla de Lepanto: el instante en que don Juan, convertido en un nuevo David, alzaba la cabeza del Bajá de los turcos (Oviedo, 1572: 46r).

En otra ocasión dimos cuenta del recorrido de estas imágenes que se insertan como grabados xilográficos en el cuerpo de la relación (García Bernal, 2007: 185, 198). Ahora solo señalar que detrás de las damas ecuestres, cerrando la máscara, desfilaban el prior, cónsules, consiliarios y diputados de la Universidad de Cargadores que ya referimos (los doce senadores, los llama Oviedo). Llevaban máscaras con barbas largas y blancas «que representauan mucha auctoridad» (Oviedo, 1572: 47r).

27. Preso en la grande victoria/ donde a Lepanto el mar baña/tropheo del de Austria y gloria/ soy en los fines de España,/ Y aunque es terrible la pena/ deste mi graue dolor/ en más áspera cadena/ me tiene preso el amor. 
JOSÉ JAIME GARCÍA BERNAL

EL CONSULADO Y LOS GREMIOS MERCANTILES DE SEVILLA EN LAS FIESTAS

POR EL TRIUNFO DE LEPANTO (ENERO-FEBRERO DE 1572)

Resumida la invención y máscara, vayamos al análisis. Como se anticipó: tradición y modernidad se cruzan en su puesta en escena. Continuidad en el uso de recursos propios de la fiesta religiosa y cívica: la batalla entre el monstruo (sierpe, dragón) y el caballero, documentada en el fasto aragonés desde el siglo XIV. Más cercana en el tiempo: la incorporación de animales fabulosos a las cuadrillas de justadores en los torneos del fasto nobiliario como la hidra y los salvajes de Valladolid (Borrego, 2014: 10). Novedad apreciable en la representación detallada de la noticia de la victoria de Lepanto y el afán de verosimilitud en la representación de sus protagonistas. Asimismo, en la aparición de la comicidad por medio del bufón o del truhán que hemos visto en otros fastos y en el teatro primitivo.

La figura del truhán adornaba las entradas de los aventureros en las fiestas de la corte, a veces sobre simulacros de dragones y sierpes, pero también a lomos de animales vivos como el camello que sacó don Fernando Âlvarez de Toledo en el torneo de 1544 (Pascual Molina, 2013: 237). Es habitual además hallarlo en breves dramatizaciones, entremeses, como en las fiestas de Milán que describe Calvete de Estrella donde actúa como narrador que tañe la vihuela (Borrego, 2014: 12; Ferrer, 1993: 195). Con este mismo papel introductor lo identifica Pilar Varela Leda (2016: 186) en la naumaquia que se hizo en Segovia, a partir del guión del Amadís, en las celebraciones de la boda de Ana de Austria. En nuestras fiestas el truhán Cazoleta, a lomos de la Sierpe, desarrolla la vis cómica mediante una gesticulación exagerada «haciendo ademanes al turco y a la gente que estaua en las ventanas» (Oviedo, 1572: 36r).

El contraste estético entre las cuadrillas de turcos y cristianos debió ser, asimismo, un recurso que activó el gusto y el entretenimiento. La disimilitud de las máscaras que representaban, del lado turco, tristeza y cautiverio, del cristiano, autoridad y gravedad, trasladaba el alcance del sacrificio cristiano y la dimensión de la derrota otomana apelando a las emociones, pero sin perder el tono festivo y alegre de este tipo de manifestaciones públicas (García Bernal, 2009: 11). Entre los ejecutantes de la máscara (los propios mercaderes y probablemente algunos actores amateurs) y el público mediaba, pese a la proximidad del acontecimiento, el pacto implícito de la simulación de la batalla que permite valorar a Oviedo «el orden y auctoridad y traça» que distinguió estas fiestas. Una experiencia distinta a la entrada del Emperador Carlos V en Troina (Sicilia), tras la conquista de Túnez, cuando recorrió sus calles, como un nuevo Escipión, seguido de un retén de prisioneros moros (Morales Folguera, 2015: 15$)^{28}$.

En la representación de la victoria se podían distinguir los integrantes de la Santa Liga, con sus armas y estandartes, contribuyendo de este modo a fijar, en la memoria

28. En Palermo, se erigió la Porta Nuova, como testimonio de la victoria africana, a la que el virrey Marco Antonio Colonna, lugarteniente de don Juan de Austria, añadirá una inscripción, ligando su fama a la del propio Emperador (Morales Folguera, 2015: 13).

Ediciones Universidad de Salamanca / @®@@ Stud. his., H. ${ }^{a}$ mod., 42, n. 2 (2020), pp. 167-193 
JOSÉ JAIME GARCÍA BERNAL

EL CONSULADO Y LOS GREMIOS MERCANTILES DE SEVILLA EN LAS FIESTAS

POR EL TRIUNFO DE LEPANTO (ENERO-FEBRERO DE 1572)

popular, una imagen fija del acontecimiento político asociada a la grandeza de sus protagonistas. La lectura bíblica de la gesta naval quedaba, sin embargo, reservada a aquellos que estaban al tanto de su organización y a los lectores de la relación:

imitando algunas cosas de la diuina escritura, mayormente aquellas en que Dios se mostró fauorable a los que de corazón pedían ser socorridos en su necessidad (Oviedo, 1572: 34v).

El favor divino tendía, de este modo, un lazo sobre la historia, anudando el alfa y la omega de los tiempos. La máscara entró por la Contratación y dio una vuelta por el primer patio de los Reales Alcázares, regresando luego a las casas del Tesorero, mientras caía la noche de aquel invierno.

\section{CONCLUSIONES}

La representación veraz, con detalles históricos precisos y actores caracterizados, fue rasgo habitual en las fiestas públicas del reinado de Felipe II. En este mismo ciclo celebrativo el gremio de sederos y lenceros imitó la entrada del monarca en la ciudad que había tenido lugar apenas dos años antes, mientras en el carro de los esparteros se representó el bautizo del príncipe, ceremonia en la que podían identificarse los principales personajes que la habían protagonizado en la corte ${ }^{29}$.

En la mayor parte de los carros de invención que hemos analizado en estas páginas predomina, sin embargo, el argumento mitológico y la tradición dinástica de los Austrias asociados al regio natalicio y los rituales cortesanos que lo envuelven. Es interesante destacar aquellos que recrean una coronación alegórica (en sustitución del inexistente rito en la tradición castellana) en la que intervienen, además, personajes vinculados a la historia de la ciudad de Sevilla.

Desde el punto de vista de la puesta en escena, las máscaras y carros de triunfo examinados acrisolan tradiciones diversas. El fasto nobiliario se cruza con la práctica escénica del drama litúrgico y ambos se enriquecen de la danza popular en este artículo apenas esbozada. Resulta fundamental, asimismo, la práctica escénica de los artesanos-actores, bien engastada en la celebración anual del Corpus. Y queda la incógnita acerca del proceso de producción de las breves representaciones que, combinando el gesto, la palabra y la música, se escenificaban sobre las plataformas móviles por las calles de la ciudad.

Los antecedentes más inmediatos de estas fiestas se encuentran en el torneo de Valladolid de 1544, en los recibimientos de Toledo (1561), Burgos y Segovia (1570) y,

29. Citamos aquí dos representaciones que, por razones de espacio, no se han analizado en estas páginas.

Ediciones Universidad de Salamanca / @®@@ Stud. his., H. ${ }^{a}$ mod., 42, n. 2 (2020), pp. 167-193 
JOSÉ JAIME GARCÍA BERNAL

EL CONSULADO Y LOS GREMIOS MERCANTILES DE SEVILLA EN LAS FIESTAS

POR EL TRIUNFO DE LEPANTO (ENERO-FEBRERO DE 1572)

desde luego, en el de Sevilla que relató Mal Lara (para otra ocasión quedará hablar de sus consecuentes como el recibimiento de Valencia de 1586 que representó asimismo la batalla de Lepanto). Espectacularidad de artificios y rasgos de comicidad beben de estos modelos, si bien destaca en las máscaras de Sevilla (y bien que lo sabía Pedro de Oviedo) la gala y la riqueza. No es de extrañar considerando que los principales oficios mercantiles de la ciudad fueron sus artífices acudiendo a la convocatoria del cabildo. Junto a ellos, los organismos vinculados con el negocio americano: la Casa de la Contratación y el Consulado de mercaderes. Queda aún mucho por averiguar de la intervención de dichas instituciones en estas fiestas y esperemos que la futura investigación ofrezca novedades en este sentido.

\section{BIBLIOGRAFÍA}

Abadía Flores, C. (2010). La comunidad flamenca en Sevilla en el siglo XVI. Archivo Hispalense, 93, pp. 173-192.

Albardonero Freire, A. (2000). Fuentes legales sobre construcción. Las Ordenanças de Sevilla (1527). En: Actas del III Congreso Nacional de Historia de la Construcción. Granada: CEHOPU.

Albardonero Freire, A. (2015). La alameda un jardín público de árboles y agua. Origen y evolución del concepto. Anuario de Estudios Americanos, 72(2), 321-425.

Álvarez Nogal, C. (1998). Finanzas y comercio en el siglo XVII: la crisis de la avería. En Actas del VII Congreso Internacional de Historia de América (vol. III, pp. 1365-1374). Zaragoza: Gobierno de Aragón, Departamento de Educación, Cultura y Deporte).

Bernal, M. (1998). Juan de Mal Lara y su «Recibimiento», estudio preliminar a Juan de Mal Lara, Recebimiento que bizo la muy noble y muy leal ciudad de Senilla a la C.M.R. del rey D. Phelipe N.S. Sevilla: Fundación el Monte.

Bernal, A. M. (2013). Las corporaciones mercantiles de Sevilla: del Consulado (1543) a la Cámara de Comercio (1886). Anuario de Estudios Atlánticos, 59, 253-288.

Bernal, A. M., A. Collantes de Terán, A. García-Baquero. (2008). Sevilla, de los gremios a la industrialización. Sevilla: Ayuntamiento de Sevilla, ICAS.

Bejarano Pellicer, C. (2010). Medios de comunicación en la ciudad durante la Edad Moderna: la figura del pregonero. En A. Castillo Gómez y J. S. Amelang (coord.), Opinión pública y cultura urbana en la Edad Moderna. Alcalá de Henares: Trea.

Bejarano Pellicer, C. (2015). Los sonidos de la ciudad. El paisaje sonoro de Sevilla, siglos XVI al XVIII. Sevilla: Ayuntamiento de Sevilla.

Borrego Gutiérrez, E. (2014). «Parateatralidad y fiesta cortesana en el Quinientos: motivos cómicos en el camino hacia la comedia nueva». En J. M. Díez Borque (dir.), A. Bustos Táuler (ed. lit.), E. Di Pinto (ed. lit.), ¿Hacia el gracioso? Comicidad en el teatro español del siglo XVI (pp. 179-205). Visor Libros.

Bustos Táuler, A. (2016). «Juan del Encina, Francisco de Madrid y el género de la égloga política sayaguesa», Criticón, 126, 15-29.

Ediciones Universidad de Salamanca / @®@@ Stud. his., H. ${ }^{a}$ mod., 42, n. 2 (2020), pp. 167-193 
JOSÉ JAIME GARCÍA BERNAL

EL CONSULADO Y LOS GREMIOS MERCANTILES DE SEVILLA EN LAS FIESTAS

POR EL TRIUNFO DE LEPANTO (ENERO-FEBRERO DE 1572)

Calvete de Estrella, J. C. (2001). El felicíssimo viaje del muy alto y poderoso príncipe don Phelippe (Edición de Paloma Cuenca). Madrid: Sociedad Estatal para la conmemoración de los centenarios de Felipe II y Carlos V.

Castillejo Benavente, A. (2019). La imprenta en Sevilla en el siglo XVI (1521-1600). Sevilla: EUS.

Cátedra, P. (2000). Fiestas caballerescas en tiempos de Carlos V, en A. J. Morales, La fiesta en la Europa de Carlos V. Madrid: Sociedad Estatal para la conmemoración de los centenarios de Felipe II y Carlos V.

Collantes de Terán, A. (1980). La formación de los gremios sevillanos. A propósito de unos documentos sobre tejedores, En la España medieval, 1, 89-104.

Collantes de Terán, A. (1984). Sevilla en la Baja Edad Media. La ciudad y sus hombres. Sevilla: Ayuntamiento de Sevilla.

Fernández Chaves, F. M y Pérez García, R. M. (2009). En los márgenes de la ciudad de Dios. Moriscos en Sevilla. Valencia: Universitat de Valencia.

Fernández Travieso, A. (2007), Álvar Gómez de Castro. Recebimiento que la imperial ciudad de Toledo bizo a la magestad de la reina nuestra señora doña Isabel (Toledo, 1561). A Coruña: SIELAE.

Ferrer Valls, T. (1987). Orígenes y desarrollo de la práctica escénica cortesana: del fasto medieval al teatro áulico en el reinado de Felipe III. Tesis Doctoral. Universitat de Valencia.

Ferrer Valls, T. (1991). La práctica escénica cortesana: de la época del Emperador a la de Felipe III. London: Tamesis Books.

Ferrer Valls, T. (2005). «El espectáculo de la fe: manifestaciones religiosas de la fiesta pública en el siglo XVI». Criticón, 94-95, 121-135.

García Bernal, J. J. (2006). El fasto público en la España de los Austrias. Sevilla: Universidad de Sevilla.

García Bernal, J. J. (2007). «Velas y estandartes: imágenes festivas de la Batalla de Lepanto». I/C. Revista Científica de Información y Comunicación, 4, 172-211.

García Bernal, J. J. (2008). «El imaginario político del Mediterráneo en la Relación de las suntuosas y ricas fiestas de Pedro de Oviedo». En P. Civil, F. Crémoux y J. Sanz (eds.), España y el mundo mediterráneo a través de las relaciones de sucesos (1500-1750). Salamanca: Ediciones Universidad de Salamanca.

García Bernal, J. J. (2009). Fisiognomía y código estético de las mascaradas públicas del barroco hispano: crítica y evolución del concepto de la mascarada jocoseria. En C. de la Peña et alii (coords.), Congreso Internacional Imagen y Apariencia (siglos XVI-XXI). Murcia: Universidad de Murcia.

García Bernal, J. J. (2018). La Fama: alegoría y síntesis en las cabalgatas festivas del mundo hispánico (siglo XVI). En B. Perez (dir.), La Reputación. Quête individuelle et aspiration collective dans l'Espagne des Habsbourg. Hommage à la professeure Araceli Guillaume-Alonso. Paris: Sorbonne Université Presses.

Gómez-Salvago Sánchez, M. (1998). Fastos de una boda real en la Sevilla del Quinientos (estudio y documentos). Sevilla: Universidad de Sevilla.

Ediciones Universidad de Salamanca / @@@ Stud. his., H. ${ }^{a}$ mod., 42, n. 2 (2020), pp. 167-193 
JOSÉ JAIME GARCÍA BERNAL

EL CONSULADO Y LOS GREMIOS MERCANTILES DE SEVILLA EN LAS FIESTAS

POR EL TRIUNFO DE LEPANTO (ENERO-FEBRERO DE 1572)

González Arce, J. D. (1991). «Sobre el origen de los gremios sevillanos», En la España Medieval, 14, 163-182.

Granja, A. de la (1988). El entremés y la fiesta del Corpus, Criticón, 42, 139-153.

Hertz, D. (1975). Un divertissement de Palais pour Charles Quint à Binche. En J. Jacquot (ed.), Les Fêtes de la Renaissance. Fêtes et cérémonies au temps de Charles Quint, II. Paris: CNRS.

Heredia Herrera, A. (1983). Historia de un depósito documental: el archivo del consulado de cargadores en Sevilla. En Andalucía y América en el siglo XVI, vol. I. Sevilla: Escuela de Estudios Hispanoamericanos.

Hermenegildo, A. (2009). Figuras reales en el códice de autos viejos: teatralización y dramatización de la catequesis. Castilla. Estudios de Literatura, 0, 166-191.

Jiménez Montes, G. (2016). Las redes comerciales del norte de Europa en el suministro de madera a Andalucía de 1581 a 1621. En M. García Fernández (ed.), Familia, cultura material y formas de poder en la España Moderna. Valladolid: FEHM.

Lleó Cañal, V. (1975). Arte y espectáculo: la fiesta del Corpus Christi en la Sevilla de los S. XVI y XVII. Sevilla: Diputación.

Lleó Cañal, V. (1979). Nueva Roma. Mitología y humanismo en el Renacimiento sevillano. Sevilla: Diputación.

Lleó Cañal, V. (1980). Fiesta grande: el Corpus Christi en la historia de Sevilla. Sevilla: Ayuntamiento de Sevilla.

Mal Lara, J de. (1998). Recebimiento que bizo la muy noble y muy leal cindad de Senilla a la C.M.R. del rey D. Phelipe N.S. (Edición y Estudios de Miguel Bernal y Antonio Miguel Bernal). Sevilla: Fundación el Monte.

Mínguez, V. (2011). Iconografía de Lepanto. Arte, propaganda y representación simbólica de una monarquía universal y católica. Obradoiro de Historia Moderna, 20, 251-280.

Morales Folguera, J. M. (2015). El viaje triunfal de Carlos V por Sicilia tras la victoria de Túnez. Imago, 7, 7-21.

Ojeda Calvo, V. (2007). Stefanelo Botarga e Zan Ganassa. Scenari e zibaldoni di comici italiani nella Spagna del cinquecento. Roma: Bulzoni.

Ordenanças de Sevilla. Qve por sv original son abora nvenamente impressas (...) Recopilación de las ordenanças de la moy noble, y moy leal Cibdad de Sevilla (1632). Sevilla: Andrés Grande.

Otte Sander, E. (2008). Sevilla, siglo XVI: Materiales para su historia económica. Sevilla: Consejería de la Presidencia.

Oviedo, P. (1572). Relación de las sumptosas y ricas fiestas que la insigne ciudad de Seuilla bizo por el felice nascimiento del príncipe nuestro Señor. Y por el vencimiento de la batalla naual que el serenísimo de Austria ono contra el armada del Turco. Sevilla: Hernando Díaz.

Quirante Santacruz, L. (1995). De les Torrens dels Serrans a la Seu y viceversa: relaciones entre teatro religioso y entradas reales en la Valencia del siglo XV. En F. Pedraza y R. González Cañal (eds.), Los albores del teatro español. Universidad de Castilla-La Mancha y Festival de Almagro. 
JOSÉ JAIME GARCÍA BERNAL

EL CONSULADO Y LOS GREMIOS MERCANTILES DE SEVILLA EN LAS FIESTAS

POR EL TRIUNFO DE LEPANTO (ENERO-FEBRERO DE 1572)

Pascual Molina, J. F. (2013). Fiesta y poder. La corte en Valladolid (1502-1559). Valladolid: Universidad de Valladolid.

Pascual Molina, J. F. (2016). Magnificencia y poder en los festejos caballerescos de la primera mitad del siglo XVI. En I. Rodríguez Moya y V. Mínguez (dir.), Visiones de un imperio en fiesta. Madrid: Fundación Carlos de Amberes.

Pérez García, R. M. (2016). El capital burgalés y la conexión de Sevilla con eje económico del norte de Europa a comienzos del reinado de Carlos I. En J. J. Iglesias Rodríguez y J. J. García Bernal (coords.), Andalucía en el mundo atlántico moderno. Agentes y escenarios. Madrid: Sílex.

Reyes, M de los (2018). El teatro español en la primera mitad del Quinientos. Historia, variaciones y estado de la cuestión. Revista de Estudios Extremeños, 74, 13-36.

Rodríguez Vicente, E. (1977). Los cargadores a Indias y su contribución a los gastos de la Monarquía. 1555-1750. Anuario de Estudios Americanos, 34, 211-232.

Rufo Ysern, P. (1993). El Corpus Christi en Écija. En Écija en la Edad Media y el Renacimiento. Actas del III Congreso de Historia. Sevilla: Universidad de Sevilla.

Sentaurens, J. (1984). Seville et le théatre de la fin du moyen âge a la fin du XVIIè siècle, 2 vols. Bordeaux: Presses Universitaires de Bordeaux.

Sardone, S. (2016). Redes y negocios de los hermanos Ruy Díaz de Segura y Pedro Gutiérrez entre Sevilla y las Indias (siglo XVI). En Stefan Rinke (ed.), Entre Espacios: La historia latino-americana en el contexto global. Berlin: Freie Universität.

Vallejo Naranjo, C. (2008). La caballería en el arte de la Baja Edad Media. Sevilla: Universidad de Sevilla.

Varela Ledo, P. (2016). Relación verdadera del recibimiento que la ciudad de Burgos hizo a la reina Doña Anna de Austria en 1570. A Coruña: Sielae.

Vila Vilar, E. (2016). El consulado de Sevilla de mercaderes a Indias. Un órgano de poder. Sevilla: Ayuntamiento de Sevilla, ICAS.

Ediciones Universidad de Salamanca / @®@@ Stud. his., H. ${ }^{a}$ mod., 42, n. 2 (2020), pp. 167-193 
